Tohoku J. Exp. Med., 2000, 192, 87-98

Case Report

\title{
Induction of Apoptosis in Vivo and in Vitro in Hairy Cell Leukemia Treated by Deoxycoformycin
}

\author{
Kazuei Ogawa, Tsutomu Shichishima, Naoya \\ NAKAMURA ${ }^{1}$ and Yukio MaruYama \\ The First Department of Internal Medicine, and \\ ${ }^{1}$ Department of Pathology, Fukushima Medical University, \\ Fukushima 960-1295
}

\begin{abstract}
Ogawa, K., Shichishima, T., Nakamura, N. and Maruyama, Y. Induction of Apoptosis in Vivo and in Vitro in Hairy Cell Leukemia Treated by Deoxycoformycin. Tohoku J. Exp. Med., 2000, 192 (1), 87-98_ The leukemic cells of a patient with hairy cell leukemia were treated in vitro with 2 '-deoxycoformycin $(\mathrm{dCF})$, an inhibitor of adenosine deaminase, and deoxyadenosine (dAdo). Following this treatment, viability of the hairy cells progressively declined, and DNA fragmentation was observed. When the patient was treated with $4 \mathrm{mg} / \mathrm{m}^{2} \mathrm{dCF}$ intravenously, hairy cells in his peripheral blood rapidly decreased, and a large number of TUNEL (terminal deoxynucleotidyl transferase-mediated dUTP- biotin nick end-labeling)-positive cells were detected in a bone marrow biopsy specimen. These findings indicate that $\mathrm{dCF}$ induced apoptosis of hairy cells both in vivo and in vitro. Furthermore, bcl-2 mRNA was down-regulated by dCF and dAdo in the hairy cells in vitro. Our results suggest the importance of bcl-2 mRNA regulation in apoptotic cell death mediated by dCF in hairy cell leukemia. —— hairy cell leukemia; apoptosis; 2'-deoxycoformycin; bcl-2 (C) 2000 Tohoku University Medical Press
\end{abstract}

Hairy cell leukemia (HCL) is a rare chronic lymphoproliferative disorder. Cytoplasmic projections resembling hairs or ruffles are characteristic features of HCL. Hairy cells appear to be at a late stage of B-cell lineage and are clonal cells which are more mature compared with other chronic B-cell diseases, such as prolymphocytic leukemia and chronic lymphocytic leukemia (CLL). More than $90 \%$ of HCL patients require treatment at some time during the course of their disease. Although splenectomy had been the standard initial treatment since the late 1970's, recently HCL has been treated with interferon- $\alpha$ and purine nucleoside analogues, resulting in high rates of remission (Chang et al. 1992). The purine nucleoside analogues, 2'-deoxycoformycin (dCF), 2-chlorodeoxyadenosine,

Received June 20, 2000; revision accepted for publication September 13, 2000.

Address for reprints: Yukio Maruyama, The First Department of Internal Medicine, Fukushima Medical University, 1 Hikariga-oka, Fukushima 960-1295, Japan. 
and fludarabine, are highly effective. The overall response rate to treatment with $\mathrm{dCF}$ is $96 \%$, with $59 \%$ of the patients having complete remission (Spiers et al. 1987). However, the exact mechanism of action of dCF in HCL is unknown. Here, we report a case of HCL treated with dCF in which dCF induced apoptosis in the leukemic cells in vitro and in vivo.

\section{CASE REPORT}

A 67-year-old Japanese man, who was diagnosed as HCL and received a splenectomy in another hospital in 1992, was admitted to our hospital in October 1995 because of leukocytosis, anemia, and thrombocytopenia. On admission, his red blood cell count was $248 \times 10^{10} /$ liter, hemoglobin was $84 \mathrm{~g} /$ liter, hematocrit was $26.8 \%$, platelet count was $60 \times 10^{9} /$ liter, and white cell count (WBC) was $64.1 \times 10^{9} /$ liter with a differential count of $1 \%$ band forms, $3 \%$ segmented forms, $5 \%$ lymphocytes, and $86 \%$ hairy cells. The hairy cells in his peripheral blood showed fine hair-like cytoplasmic projections and oval nuclei with coarse chromatin. A bone marrow core biopsy was done because marrow aspiration resulted in a dry tap. The bone marrow showed extensive infiltration of hairy cells (Fig. 1A), with weakly positive tartrate-resistant acid phosphatase staining. His peripheral blood hairy cells were positive for CD19, CD20, CD11c, CD25, SmIgD and HLA-DR and negative for CD3, CD4, CD8, CD5, CD21, CD24, and other myeloid cell antigens. No chromosomal abnormality was detected in his peripheral blood. The patient was diagnosed as having an exacerbation of hairy cell leukemia. Prior to dCF therapy, informed consent was obtained from the patient.

\section{Materials and Methods}

\section{Drugs}

2'-deoxycoformycin was a gift from The Chemo-Sero Therapeutic Research Institute, Kumamoto. Pentostatin, which was used for the therapy, was obtained from Nippon Kayaku Co., Ltd (Tokyo). Deoxyadenosine (dAdo) was purchased from Nakarai Tesque Inc. (Kyoto).

\section{Cell isolation and incubation}

Peripheral blood was collected in heparinized tubes and centrifuged at $400 \times$ $g$ for 10 minutes. The mononuclear cells were isolated from the buffy coat using a Ficoll-Isopaque (Pharmacia, Uppsala, Sweden) gradient. For purification of hairy cells, mononuclear cells were tested with specific monoclonal antibodies, CD1lc and CD25 using a FACScan (Becton-Dickinson and Co., Franklin Lakes, CA, USA). Cells $\left(10 \times 10^{5} / \mathrm{ml}\right)$ were incubated in RPMI1640 medium (Gibco, Europe, Paisley, UK) containing 10\% FCS (Gibco) and dCF $(50 \mu \mathrm{M})$ alone, dAdo $(10 \mu \mathrm{M})$ alone, $\mathrm{dCF}(50 \mu \mathrm{M})$ and dAdo $(10 \mu \mathrm{M})$, or without additives in a humidified incubator $37^{\circ} \mathrm{C}$ in air containing $5 \% \mathrm{CO}_{2}$. Cell viability was deter- 


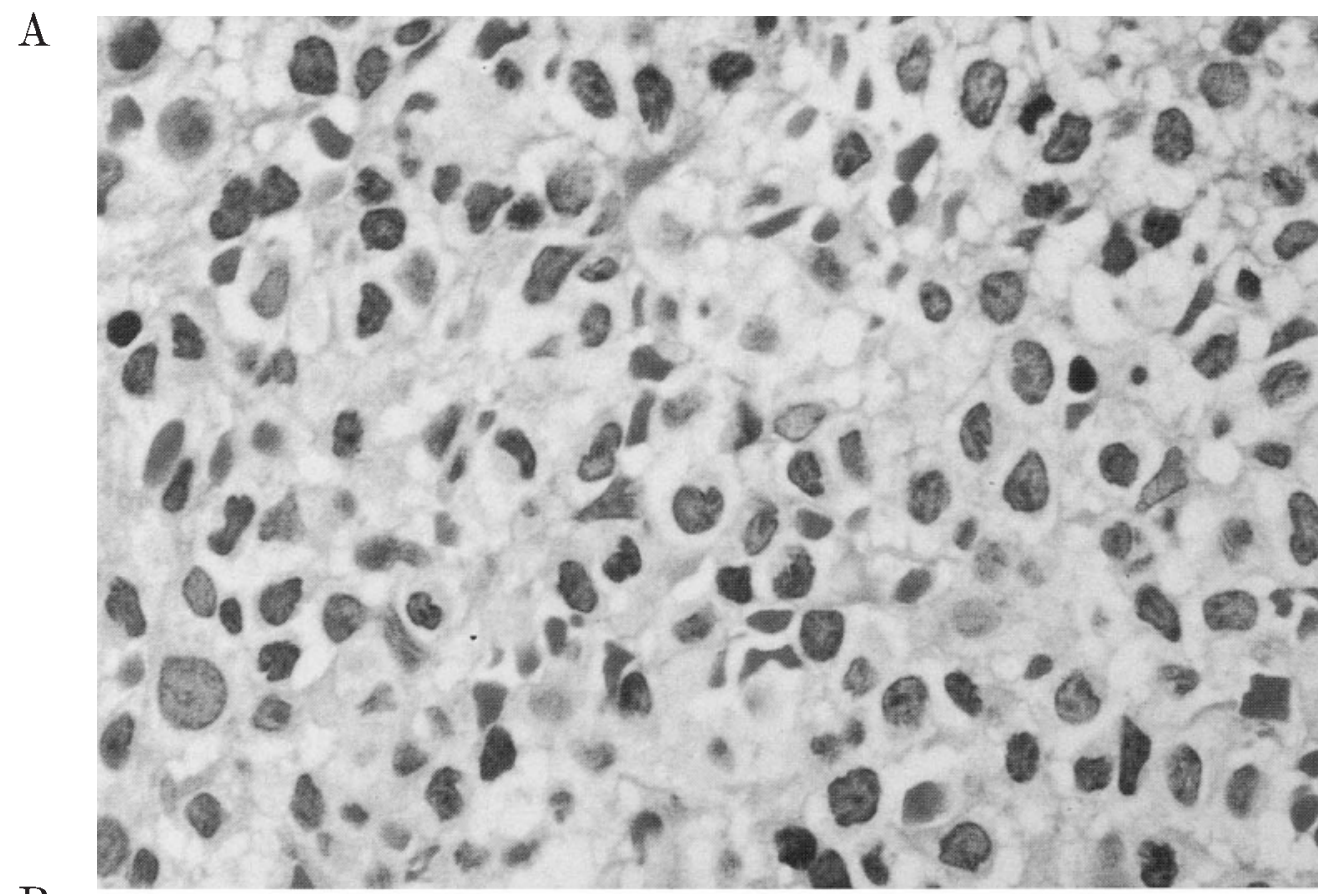

$\mathrm{B}$

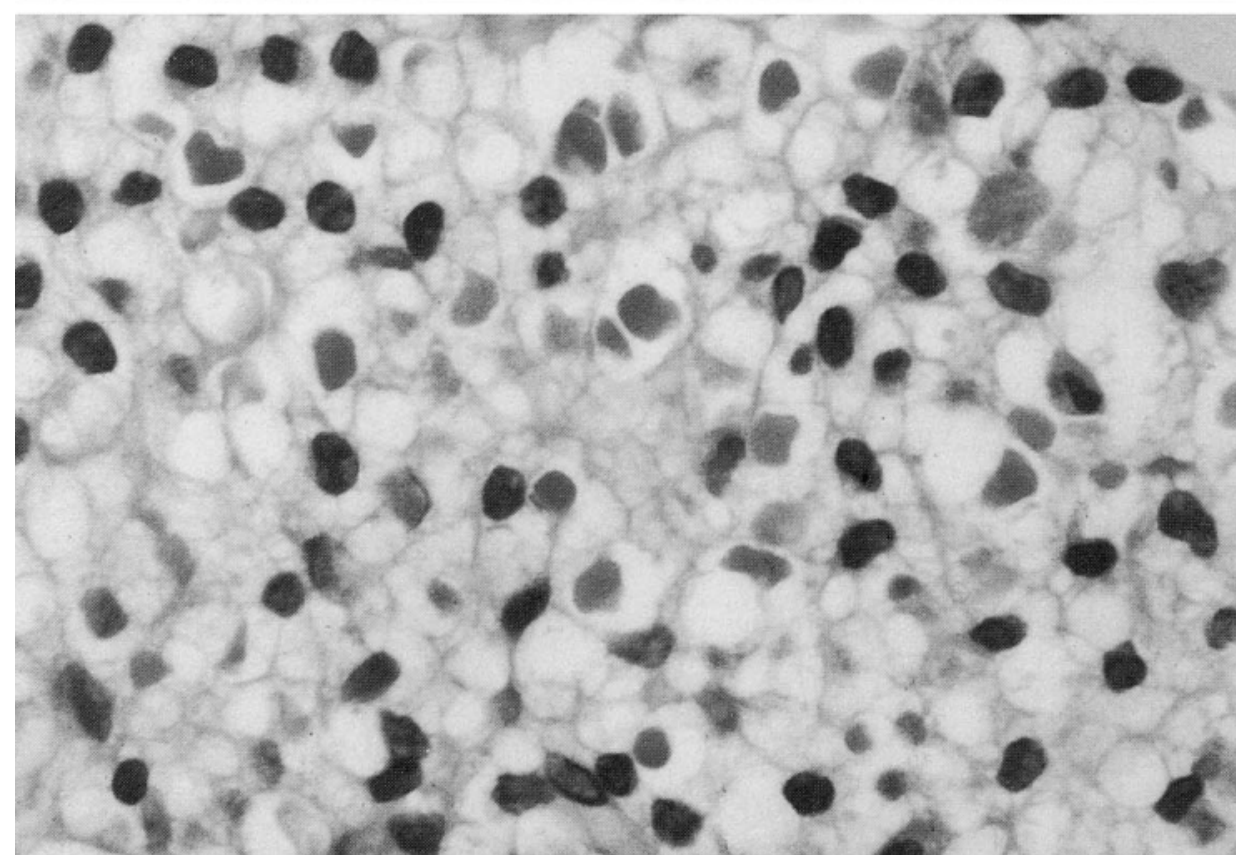

Fig. 1. Bone marrow biopsy sections obtained on admission (A) and after dCF administration $(\mathrm{B})(\mathrm{H} \& \mathrm{E}, \times 132)$. After dCF administration, nuclei show chromatin condensation $(\mathrm{B})$.

mined by trypan blue exclusion.

Agarose gel electrophoresis of DNA

Cells were incubated in RPMI medium for 48 hours as described above, and were then harvested and treated with $100 \mu \mathrm{g} / \mathrm{ml}$ proteinase $\mathrm{K}$ (Sigma Chemical Co., St. Louis, MO, USA) and $0.1 \%$ sodium dodecyl sulfate for 90 minutes at $50^{\circ} \mathrm{C}$. The DNA was extracted with phenol and chloroform and precipitated with ethanol. The precipitate was resuspended in TE buffer (10 mM Tris-HCL, pH 8.0 
and $1 \mathrm{mM} \mathrm{EDTA}$ ) and treated with DNase-free RNase (Boehringer, Mannheim, Germany) for 2 hours at $37^{\circ} \mathrm{C}$. The concentration of DNA was measured spectrophotometrically, and $10 \mu \mathrm{g}$ of each DNA sample was then fractionated by electrophoresis on a $1.5 \%$ agarose gel containing $0.4 \mu \mathrm{g} / \mathrm{ml}$ ethidium bromide. DNA was visualized with a UV $(302 \mathrm{~nm})$ transilluminator, and the gel was photographed with a Polaroid camera.

\section{TUNEL staining}

Two-micrometer sections of the patient's bone marrow biopsy samples were used. TUNEL was performed as described previously (Gavrieli et al. 1992) with minor modifications. Briefly, nuclei in the tissue sections were stripped of proteins by incubation with $20 \mu \mathrm{g} / \mathrm{ml}$ proteinase $\mathrm{K}$ for 15 minutes at room temperature. The slides were incubated with $2 \% \mathrm{H}_{2} \mathrm{O}_{2}$ for 5 minutes to inactivate endogenous peroxidase and were then incubated for 60 minutes at $37^{\circ} \mathrm{C}$ with $0.3 \mathrm{EU} / \mu \mathrm{l}$ TdT (Takara Shuzo Co., Kyoto) and $0.04 \mathrm{nmol} / \mu \mathrm{l}$ biotinylated dUTP (Boeringer) in TdT buffer containing $30 \mathrm{mM}$ Tris-HCL, pH 7.2, $140 \mathrm{mM}$ sodium cacodylate, and $1 \mathrm{mM}$ cobalt chloride. The reaction was terminated with buffer containing $300 \mathrm{mM} \mathrm{NaCl}$ and $30 \mathrm{mM}$ sodium eitrate. The slides were coated with avidin-conjugated peroxidase (Medical and Biological Laboratories Co., Nagoya) diluted 1:3000 in PBS and visualized using 3, 3'-diaminobenzidine and $\mathrm{H}_{2} \mathrm{O}_{2}$. TdT-positive nuclei were dark brown under light microscopy.

\section{$R N A$ preparation and Northern blot analysis}

Total cellular RNA was extracted in the presence of guanidium isocyanate. Samples containing $15 \mu \mathrm{g}$ of RNA were denatured at $65^{\circ} \mathrm{C}$ in $50 \%$ formamide, electrophoresed on a $1.1 \%$ agarose gel containing $6 \%$ formaldehyde, and then transferred to a nylon membrane (Biodyne, Pall, Co., East Hills, NY, USA) in $20 \times$ sodium chloride-sodium citrate. The bcl-2 probe(Oncogene Science, Inc., Cambridge, MA, USA), including the major breakpoint region within the $3^{\prime}$ noncoding segment of the second exon of the gene (Cleary and Sklar 1985), was prepared by randomized labeling using ${ }^{32} \mathrm{P}-\mathrm{dCTP}$. After prehybridization, the membrane was hybridized with the randomly labeled ${ }^{32} \mathrm{P}$ probe at $42^{\circ} \mathrm{C}$ for 20 hours, washed in $2 \times \mathrm{SSC}$ and $0.1 \%$ SDS for 30 minutes at room temperature, and twice in $0.1 \times \mathrm{SSC}$ and $0.1 \%$ SDS for 30 minutes at $55^{\circ} \mathrm{C}$. The blot was exposed to $\mathrm{X}$-ray film for 48 hours at $-80^{\circ} \mathrm{C}$.

\section{Immunohistochemistry}

Immunoperoxidase staining of Bcl-2 oncoprotein (clone 124, DAKO A/S, Glostrup, Denmark) in paraffin-embedded sections of biopsied bone marrow was performed using a streptavidin- biotin complex (DAKO A/S). Bcl-2 oncoprotein was used at a dilution of $1: 50$. 


\section{RESULTS}

Effect of $d C F / d A d o$ on the survival of hairy cells in vitro

The adenosine deaminase inhibitor $\mathrm{dCF}$ is known to induce apoptosis of B-CLL lymphocytes (Zinzani et al. 1994). We first examined the effect of dCF on the survival of hairy cells in vitro. Hairy cells from our patient's peripheral blood were incubated with or without dCF $(50 \mu \mathrm{M})$ and/or dAdo $(10 \mu \mathrm{M})$ and were examined every day by trypan blue exclusion until day 4 . The viability of the hairy cells progressively declined in the culture with $\mathrm{dCF}$ in the presence of dAdo. Cell viability on day 4 in control, dCF, dAdo, and $\mathrm{dCF} / \mathrm{dAdo}$ cultures was $91 \%, 90 \%, 88 \%$, and $17 \%$, respectively (Fig. 2 ). The decrease of cell viability was observed from the concentration of $1 \mu \mathrm{M}$ dAdo in the presence of dCF.

Effect of $d C F / d A d o$ on the apoptosis of hairy cells in vitro

We next investigated whether dCF induces apoptosis of hairy cells. As shown in Fig. 3, DNA fragmentation was observed in the cells treated with dCF in the presence of dAdo for 48 hours.

Clinical course and apoptosis of hairy cells in vivo

Since dCF strongly induced death of hairy cells in the presence of dAdo in vitro, we treated our patient with $\mathrm{dCF}$ (Pentostatin, $7 \mathrm{mg}$ ) which was administrated on February 6, 1996 (Fig. 4). At that time, the patient had a WBC count of

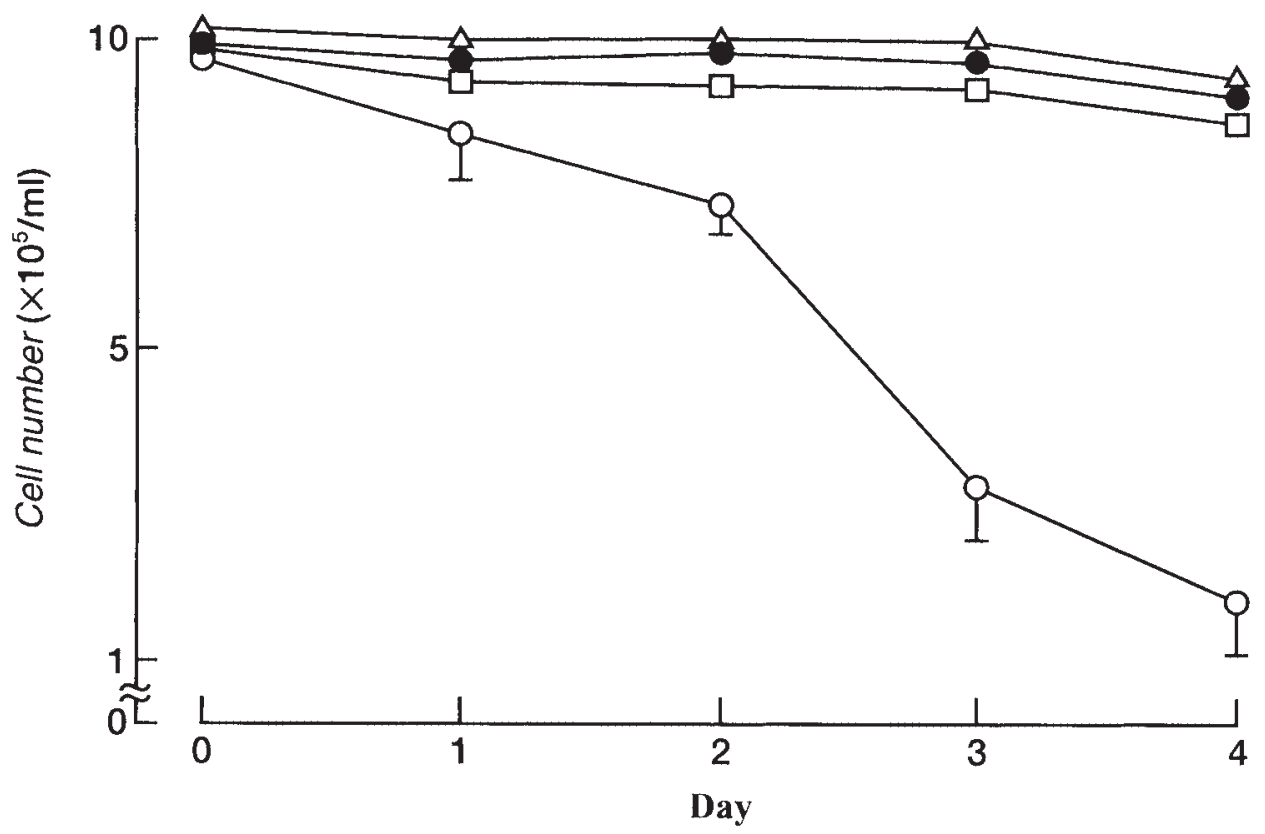

Fig. 2. The effects of dCF/dAdo on the survival of hairy cells. Hairy cells ( $10 \times$ $10^{5} / \mathrm{ml}$ ) were cultured in RPMI 1640 medium containing $10 \%$ FCS with or without $\mathrm{dCF}(50 \mu \mathrm{M}) /$ dAdo $(10 \mu \mathrm{M})$. Viable cells were measured by trypanblue staining. $\triangle-\triangle$, control; $\bullet-\bullet, d C F ; \square-\square, \mathrm{dAdo} ; \bigcirc-\circ, \mathrm{dCF}+\mathrm{dAdo}$ 


\section{S $\quad 1 \quad 2 \quad 3$}

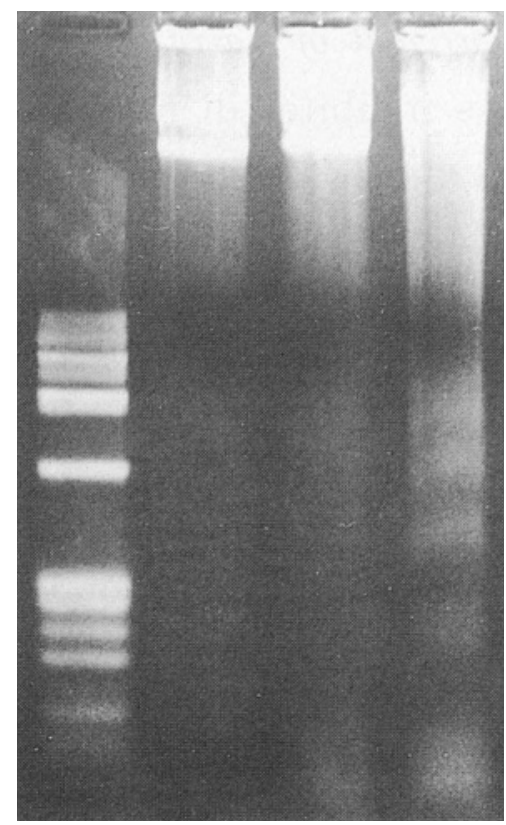

Fig. 3. DNA fragmentation in hairy cells following incubation in vitro with or without dAdo and/or dCF for 48 hours. Lane S, Size marker; Lane 1, $50 \mu \mathrm{M}$ dCF; Lane 2, $10 \mu \mathrm{M}$ dAdo; Lane 3, $50 \mu \mathrm{M} \mathrm{dCF}$ and $10 \mu \mathrm{M}$ dAdo.

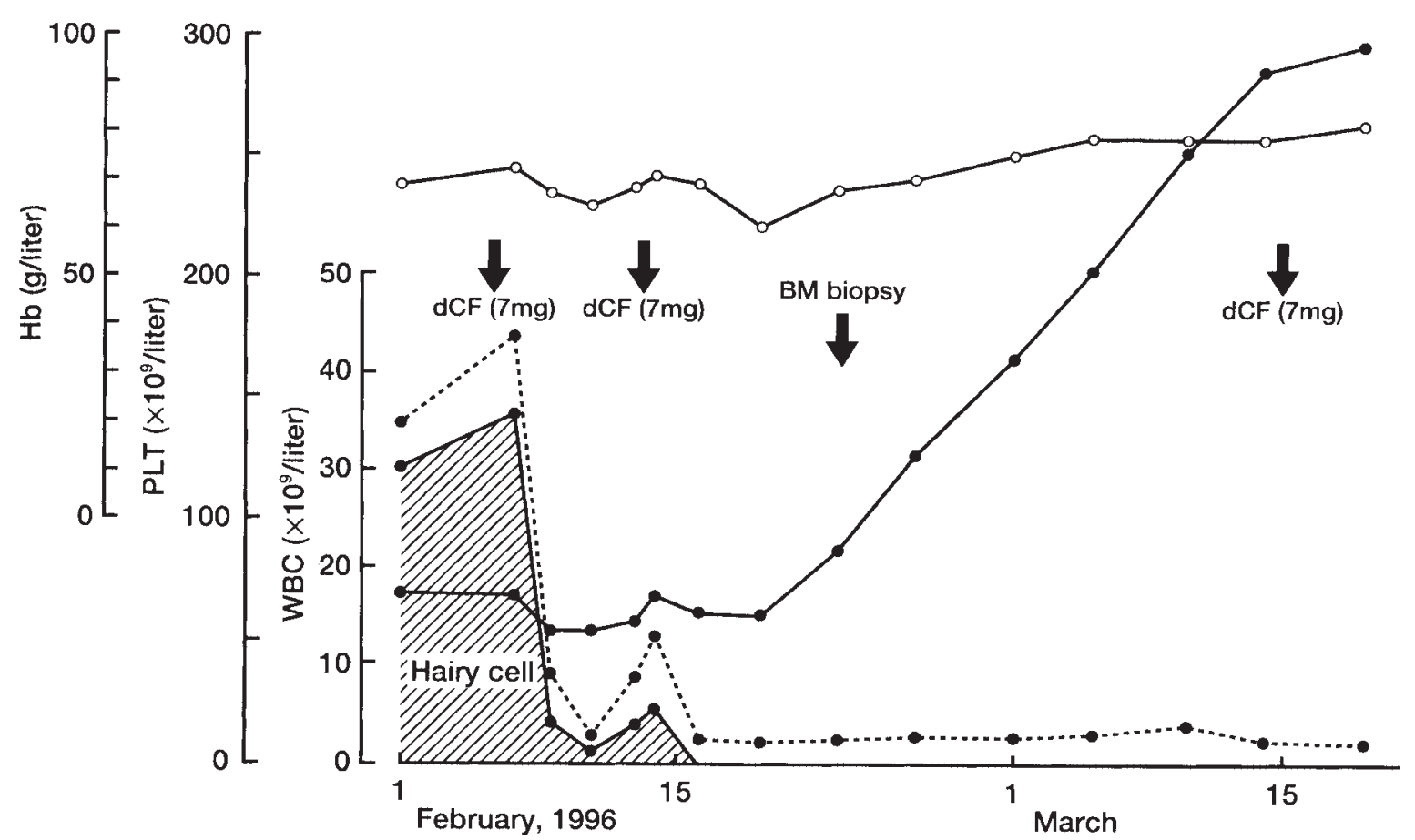

Fig. 4. Clinical course of our patient. dCF (Pentostatin, $7 \mathrm{mg}$ ) was administrated on February 6 and 13, 1996. A bone marrow biopsy was performed on February 23. Hb, hemoglobin; PLT, platelet count; WBC, white blood cell count; BM, bone marrow. $-\mathrm{O}, \mathrm{Hb}$; - $\bullet$ PLT; $\bullet . . . . \bullet$. WBC. 
$33.4 \times 10^{9} /$ liter with $89 \%$ hairy cells, hemoglobin concentration of $69 \mathrm{~g} /$ liter, and platelet count of $70 \times 10^{9} /$ liter. Pentostatin was administrated again on February 13. Following the first $\mathrm{dCF}$ treatment, his WBC count rapidly decreased and hairy cells in the peripheral blood had disappeared on February 16. Thereafter, platelets gradually increased and reached $285 \times 10^{9} /$ liter on March 15. The cell surface proteins, CD11c and CD25, which are characteristic markers of hairy cells, also decreased to very low levels on March 25. To examine the effects of dCF on the apoptosis of hairy cells in vivo, a bone marrow biopsy was performed on day 17 (February 23) after the first administration of dCF. As shown in Fig. 5B, a large number of TUNEL-positive cells were observed in the bone marrow biopsy sample obtained after treatment with dCF, while few TUNEL-positive cells were present in the biopsy obtained on admission (Fig. 5A). With hematoxylin-eosin $(\mathrm{H} \& \mathrm{E})$ staining, TUNEL-positive cells could be observed which did not have all the morphological features of typical apoptosis, but the nuclei after dCF treatment (Fig. 1B) were more condensed compared with those on admission (Fig. 1A).

\section{Effect of $d C F / d A d o$ on the expression of bcl-2 in hairy cells}

Immunohistochemical examination with monoclonal antibody specific for human bcl-2 protein showed a high expression of bcl-2 in hairy cells in the patient's bone marrow on admission (Fig. 6). The change in bcl-2 expression during apoptosis induced in vitro by dCF and dAdo was examined by Northern blot analysis. The bcl-2 specific probe detected mRNA transcripts (approximately $8.5 \mathrm{~kb}$ ) in hairy cells. Bcl-2 mRNA decreased 24 hours after the addition of $\mathrm{dCF}$ and dAdo, and was remarkably downregulated 48 hours later (Fig. 7 ).

\section{Discussion}

The exact mechanism of action of $\mathrm{dCF}$ on HCL is unknown. 2'Deoxycoformycin, a natural product isolated from the culture broth of Streptomyces antibioticus, is a tight-binding inhibitor of adenosine deaminase (Kodama et al. 1979). Adenosine deaminase is responsible for the deamination of dAdo and adenosine to deoxyinosine and inosine, respectively. Inhibition of adenosine deaminase leads to the accumulation of dAdo and deoxy-ATP (dATP) and intracellular accumulation of dAdo and dATP is toxic to lymphocytes (Glazer 1980; Kefford and Fox 1983). Seto et al. (1985) reported that in nondividing lymphocytes, for example, most hairy cells, dAdo induced DNA breaks along with the activation of poly (ADP-ribose) synthetase causing cellular depletion of nicotinamide adenine dinucleotide. Begleiter et al. (1987) reported that dAdo and dCF induced DNA single-strand breaks in HCL and CLL cells in vitro and in vivo, but the antitumor activity of $\mathrm{dCF}$ in CLL was unrelated to the induction of DNA single-strand breaks. However, dAdo/dCF has also been shown to induce DNA double-strand breaks in mouse mammary FM3A cells and CD4 ${ }^{+}$ prolymphocytic leukemic cells in vitro (Yoshioka et al. 1987; Johnston et al. 


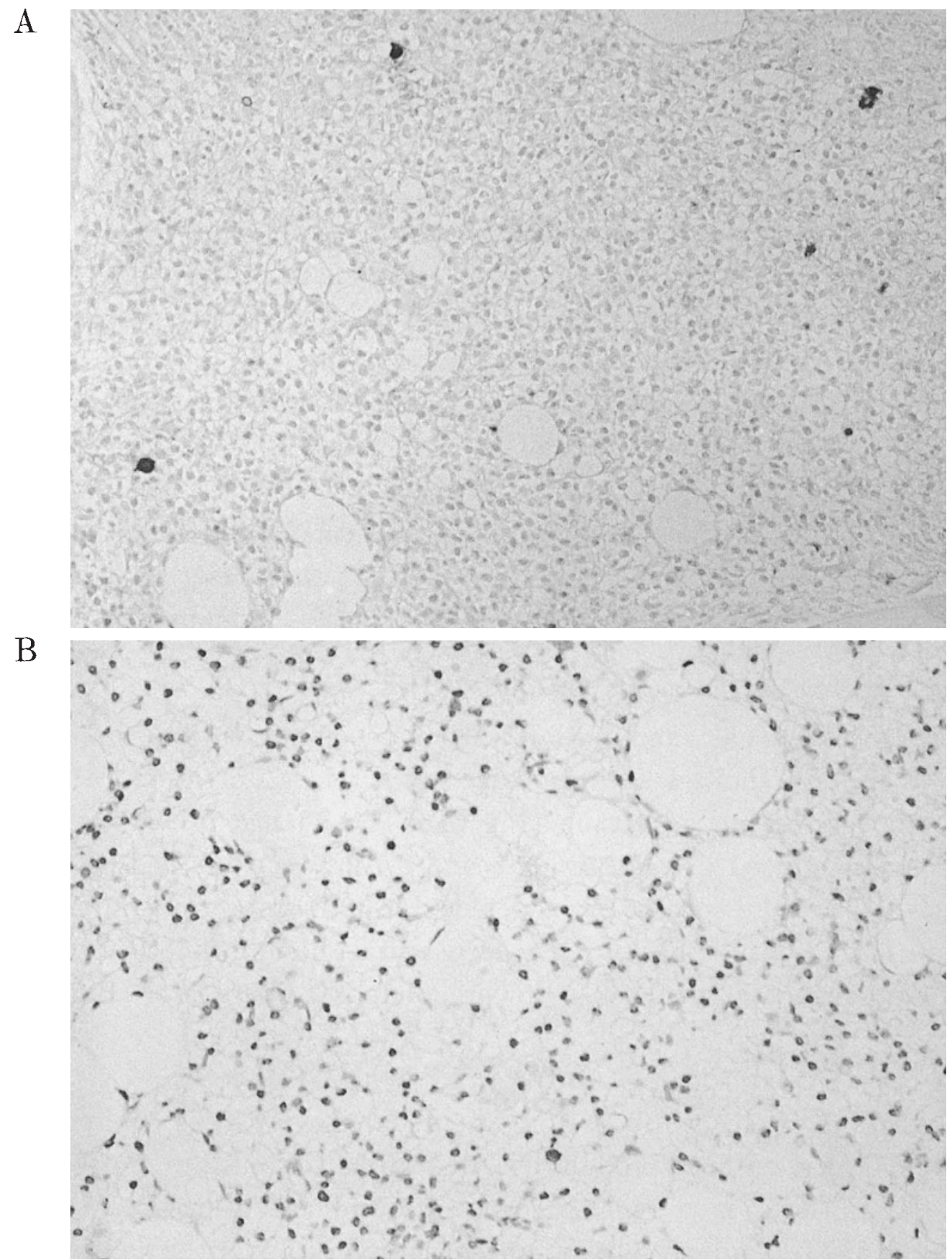

Fig. 5. TUNEL staining of a section of the bone marrow biopsy obtained from the patient on admission (October 27, 1995; A) and after dCF administration (February 23, 1996; B) $(\times 10)$. TUNEL staining was performed as described in Materials and Methods. A large number of apoptotic cells were stained brown by TUNEL(B).

1992). DNA double-strand breaks are typically observed during apoptosis as DNA fragmentation. In the present study, we demonstrated that $\mathrm{dCF} / \mathrm{dAdo}$ induces apoptosis in HCL cells in vitro and in vivo. Apoptosis is a gene-directed cellular self-destruction in which intracellular endonucleases initially cleave DNA into inter-nucleosomal fragments (180 to $200 \mathrm{bp}$ ) (Wyllie 1993). We demonstrated DNA fragmentation in hairy cells cultured with dCF/dAdo for 48 hours in 


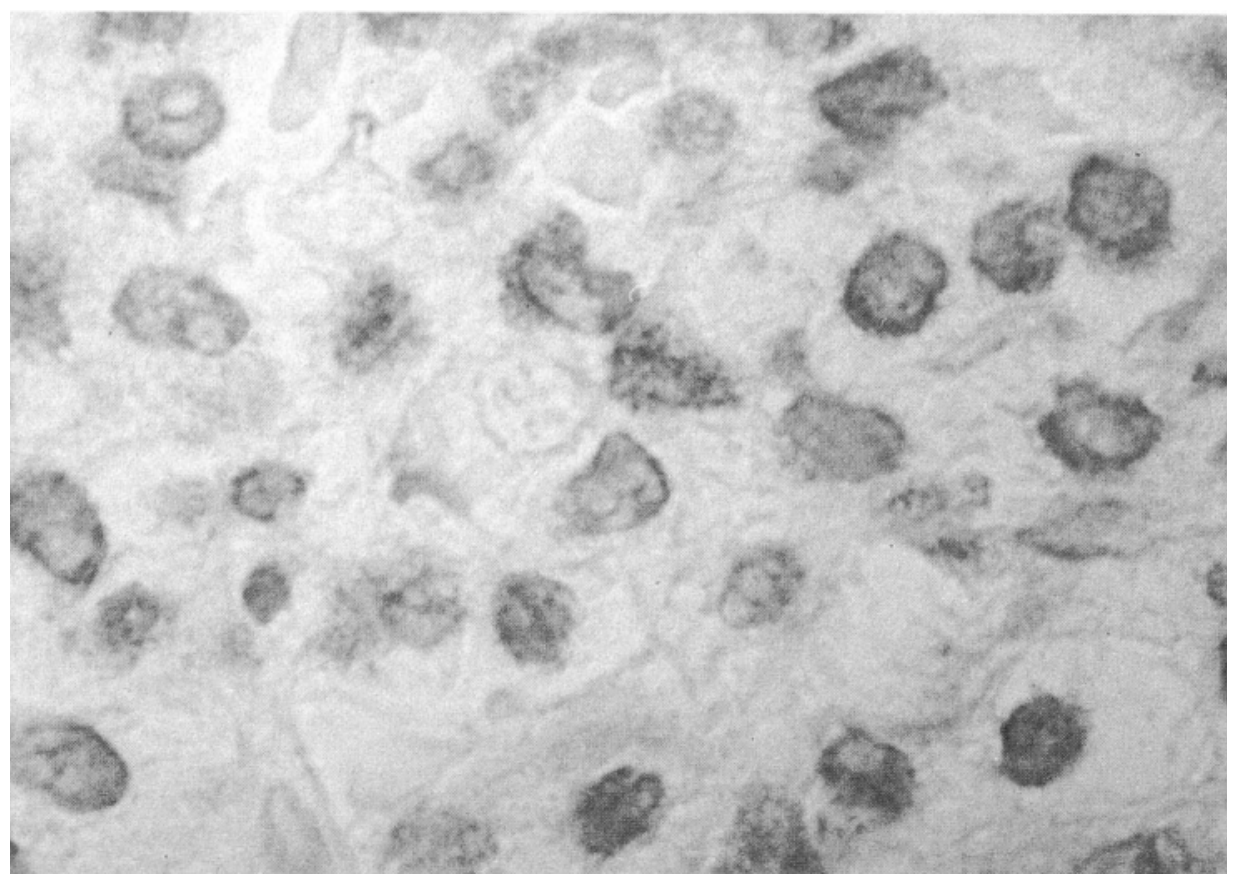

Fig. 6. Expression of bcl-2 protein $(\times 330)$. Immunohistochemical staining of bel-2 protein in a bone marrow biopsy specimen obtained on admission. Two- $\mu \mathrm{m}$ sections from the bone marrow biopsy were prepared and stained with anti-human bcl-2 antibody (brown color) as detailed in Materials and Methods.

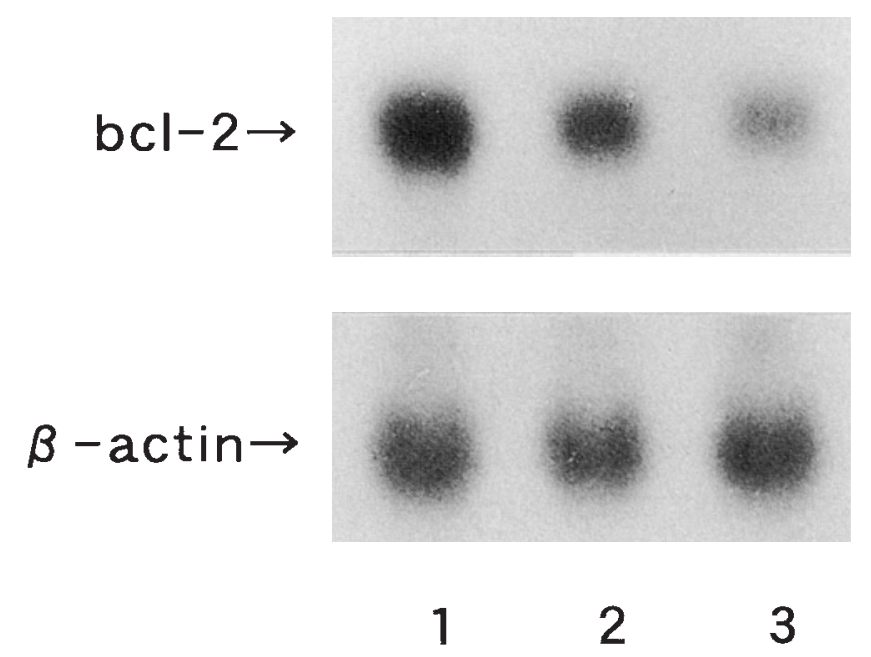

Fig. 7. Effects of dCF/dAdo on bel-2 mRNA level. Hairy cells were cultured in RPMI 1640 containg $10 \%$ FCS with $50 \mu \mathrm{M} \mathrm{dCF}$ and $10 \mu \mathrm{M}$ dAdo. Total RNA was isolated and examined by Northern blot analysis as described in Materials and Methods. Lane 1, 0 hour; Lane 2, 24 hours; Lane 3, 48 hours.

vitro (Fig. 3). Although the earlier stages of apoptosis with limited DNA fragmentation can not be identified morphologically, TUNEL staining appears to be a reliable measurement of the early stage of apoptosis in tissue sections (Gavrieli et al. 1992; Wijsman et al. 1993). Measurement of in vivo apoptosis is generally difficult because early apoptotic cells are rapidly cleared by phagocytic cells and 
macrophages (Savill et al. 1993). Some previous studies indicated evidence of the presence of apoptosis in vivo. Raza et al. (1995) reported the presence of apoptosis in bone marrow samples from myelodysplastic syndrome patients. Idink-Mecking et al. (1998) showed the occurrence of apoptosis, using an ex vivo FITC-labeled Annexin V assay, in peripheral blood lymphocytes of HCL following administration of 2-chlorodeoxyadenosine. In that report, they presumed limited phagocytotic capacity because of a previous splenectomy. We demonstrated a large number of TUNEL-positive cells in the patient's bone marrow samples after dCF administration. The presence of TUNEL-positive cells in his bone marrow samples indicated that dCF could induce apoptosis of hairy cells not only in vitro but also in vivo. In the present study, the apoptosis of hairy cells in vivo was observed by $\mathrm{dCF}$ treatment alone, although both of $\mathrm{dCF}$ and dAdo were needed in vitro. As perviously reported, $\mathrm{dCF}$ injection increased the plasma dAdo by 3.5- to 9.0- fold in CLL patients (Begleiter et al. 1987). Thus, the induction of apoptosis by $\mathrm{dCF}$ alone without dAdo in vivo may be explained by the elevation of plasma dAdo after $\mathrm{dCF}$ injection followed by intracellular accumulation of dAdo.

The bcl-2 gene was first identified at the site of a t $(14 ; 18)$ in follicular lymphomas (Tsujimoto et al. 1984). Bcl-2 and bax proteins form homodimers and heterodimers that influence the susceptibility to apoptosis. Increasing the relative concentration of bcl-2 decreases the relative sensitivity to apoptosis, whereas increasing the relative concentration of bax contributes to cell death (Yang and Korsmeyer 1996). Overexpression of bcl-2 prevents cell death including that induced by growth factor withdrawal, ionizing radiation, glucocorticoids, and multiple chemotherapeutic agents (Chen et al. 1995). High levels of bcl-2 expression was commonly found in B-CLL and follicular lymphomas (Mariano et al. 1992). Schena et al. (1992) showed a high expression of bcl-2 mRNA and protein in all the cases with CD5 ${ }^{+}$CLL clones studied, while normal CD5 ${ }^{+}$B-cells were negative. Moreover, in clinical studies, a correlation between high bcl-2 expression and poor response to chemotherapy has been reported in CLL, suggesting a possible role of bcl-2 in the development of drug resistance (Pepper et al. 1996). Mariano et al. (1992) reported that 2 of 5 patients with HCL expressed bcl-2 mRNA at detectable levels. Furthermore, Zaja et al. (1997) showed with immunohistochemical analysis of bone marrow biopsy samples that bel-2 was expressed in all of the 14 cases with HCL studied. Bcl-2 mRNA and protein were also detected in our HCL patient and the mRNA was downregulated by dCF in vitro. Chen et al. (1995) reported that apoptosis after exposure to TNF- $\alpha$, $\mathrm{C}_{2}$-ceramide, and ionizing radiation was associated with downregulation of bcl-2 mRNA in HL-60 and U937 cells. Also in B-cells of CLL, cell death and apoptosis were shown to be accompanied by a reduction in bcl-2 expression (Tangye and Raison 1996). Furthermore, fludarabine, a purine nucleoside analogue, can down-regulate bcl-2 mRNA and induce apoptosis in $\mathrm{CD} 5^{+}$leukemic B cells 
(Gottardi et al. 1998). Our findings suggest the importance of bcl-2 mRNA regulation in apoptotic cell death mediated by dCF in HCL.

\section{References}

1) Begleiter, A., Glazer, R.I., Israels, L.G., Pugh, L. \& Johnston, J.B. (1987) Induction of DNA strand breaks in chronic lymphocytic leukemia following treatment with 2'-deoxycoformycin in vivo and in vitro. Cancer Res., 47, 2498-2503.

2) Chang, K.L., Stroup, R. \& Weiss, L.M. (1992) Hairy cell leukemia. Am. J. Pathol., 97, 719-738.

3) Chen, M., Quintans, J., Fuks, Z., Thompson, C., Kufe, D.W. \& Weichselbaum, R.R. (1995) Suppression of bel-2 messenger RNA production may mediate apoptosis after ionizing radiation, tumor necrosis factor $\alpha$, and ceramide. Cancer Res., 55, 991-994.

4) Cleary, M.L. \& Sklar, J. (1985) Nucleotide sequence of a t $(14 ; 18)$ chromosomal breakpoint in follicular lymphoma and demonstration of a breakpoint-cluster region near a transcriptionally active locus on chromosome 18. Proc. Natl. Acad. Sci. USA, 82, $7439-7443$.

5) Gavrieli, Y., Sherman, Y. \& Ben-Sasson, S.A. (1992) Identification of programmed cell death in situ via specific labeling of nuclear DNA fragmentation. J. Cell. Biol., 119, 493-501.

6) Glazer, R.I. (1980) Adenosine deaminase inhibitors: Their role in chemotherapy and immunosuppression. Cancer Chemother. Pharmacol., 4, 227-235.

7) Gottardi, D., De Leo, A.M., Alfarano, A., Stacchini, A., Circosta, P., Gregoretti, M.G., Bergui, L., Aragno, M. \& Caligaris-Cappio, F. (1997) Fludarabine ability to downregulate $\mathrm{Bcl}-2$ gene product in $\mathrm{CD}^{+}$leukaemic $\mathrm{B}$ cells: in vitro/in vivo correlations. Br. J. Haematol., 99, 147-157.

8) Idink-Mecking, C.A.M., Richel, D.J., Vermes, I., Schaafsma, M.R., Reutelingsperger, C. \& Haanen, C. (1998) Ex vivo evidence of lymphocyte apoptosis in hairy cell leukemia, induced by 2-chlorodeoxyadenosine treatment. Ann. Hematol., 76, 25-29.

9) Johnston, J.B., Lee, K., Verburg, L., Blondal, J., Mowat, M.R.A., Israels, L.G. \& Begleiter, A. (1992) Induction of apoptosis in $\mathrm{CD}^{+}$prolymphocytic leukemia by deoxyadenosine and 2'-deoxycoformycin. Leuk. Res., 16, 781-788.

10) Kefford, R.F. \& Fox, R.M. (1983) Purinogenic lymphocytotoxicity: Clues to a wider chemotherapeutic potential for the adenosine deaminase inhibitors. Cancer Chemother. Pharmacol., 10, 73-78.

11) Kodama, K., Kusakabe, H., Machida, H., Midorikawa, Y., Shibuya, S., Kuninaka, A. \& Yoshino, H. (1979) Isolation of 2'-deoxycoformycin and cordycepin from wheat bran culture of aspergillus nidulans Y176-2. Agric. Biol. Chem., 43, 2375-2377.

12) Mariano, M.T., Moretti, L., Donelli, A., Grantini, M., Montagnani, G., Di Prisco, A.U., Torelli, G., Torelli, U. \& Narni, F. (1992) Bcl-2 gene expression in hematopoietic cell differentiation. Blood, 80, 768-775.

13) Pepper, C., Bentley, P. \& Hoy, T. (1996) Regulation of clinical chemoresistance by bcl-2 and bax oncoproteins in B-cell chronic lymphocytic leukaemia. $B r . J$. Haematol., 95, 513-517.

14) Raza, A., Gezer, S., Mundle, S., Gao, X.-Z., Alvi, S., Borok, R., Rifkin, S., Iftikhar, A., Shetty, V., Parcharidou, A., Loew, J., Marcus, B., Khan, Z., Chaney, C., Showel, J., Gregory, S. \& Preisler, H. (1995) Apoptosis in bone marrow biopsy samples involving stromal and hematopoietic cells in 50 patients with myelodysplastic syndromes. Blood, 86, 268-276.

15) Savill, J., Fadok, V., Henson, P. \& Haslett, C. (1993) Phagocyte recognition of cells undergoing apoptosis. Immunology Today, 14, 131-136.

16) Schena, M., Larsson, L.G., Gottardi, D., Gaidano, G., Carlsson, M., Nilsson, K. \& 
Caligaris-Cappio, F. (1992) Growth- and differentiation-associated expression of bcl-2 in B-chronic lymphocytic leukemia cells. Blood, 79, 2981-2989.

17) Seto, S., Carrera, C.J., Kubota, M., Wasson, D.B. \& Carson, D.A. (1985) Mechanism of deoxyadenosine and 2-chlorodeoxyadenosine toxicity to nondividing human lymphocytes. J. Clin. Invest., 75, 377-383.

18) Spiers, A.S.D., Moore, D., Cassileth, P.A., Harrington, D.P., Cummings, F.J., Neiman, R.S., Bennett, J.M. \& O'Connell, M.J. (1987) Remissions in hairy-cell leukemia with pentostatin (2'-deoxycoformycin). N. Engl. J. Med., 316, 825-830.

19) Tangye, S.G. \& Raison, R.L. (1996) Leukaemic CD5 ${ }^{+}$B-cell apoptosis: co-incidence of cell death and DNA fragmentation with reduced bcl-2 expression. Br. $J$. Haematol., 92, 950-953.

20) Tsujimoto, Y., Finger, L.R., Yunis, J., Nowell, P.C. \& Croce, C.M. (1984) Cloning of the chromosome breakpoint of neoplastic B-cells with the $t(14 ; 18)$ chromosome translocation. Science, 226, 1097-1099.

21) Wijsman, J.H., Jonker, R.R., Keijzer, R., Van De Velde, C.J.H., Cornellise, C.J. \& Dierendonck, J.H.V. (1993) A new method to detect apoptosis in paraffin sections: In situ end-labeling of fragmented DNA. J. Histochem. Cytochem., 41, 7-12.

22) Wyllie, A.H. (1993) Apoptosis. Br. J. Cancer, 67, 205-208.

23) Yang, E. \& Korsmeyer, S.J. (1996) Molecular thanatopsis: A discourse on the BCL2 family and cell death. Blood, 88, 386-401.

24) Yoshioka, A., Tanaka, S., Hiraoka, O., Koyama, Y., Hirota, Y. \& Wataya, Y. (1987) Deoxyribonucleoside-triphosphate imbalance death: Deoxyadenosine-induced dNTP imbalance and DNA double strand breaks in mouse FM3A cells and the mechanism of cell death. Biochem. Biophys. Res. Commun., 614, 258-264.

25) Zaja, F., Di Loreto, C., Amoroso, V., Salmaso, F., Russo, D., Silvestri, F., Fanin, R., Damiani, D., Infanti, L., Mariuzzi, L., Beltrami, C.A. \& Baccarani, M. (1997) Bcl-2 immunohistochemical evaluation in B-cell chronic lymphocytic leukemia and hairy cell leukemia before treatment with Fludarabine and 2-chloro-deoxy-adenosine. Leuk. Lymph., 28, 567-572.

26) Zinzani, P.L., Tosi, P., Visani, G., Martinelli, G., Farabegoli, P., Buzzi, M., Ottaviani, E., Salvucci, M., Bendandi, M., Zaccaria, A. \& Tura, S. (1994) Apoptosis induction with three nucleoside analogs on freshly isolated B-chronic lymphocytic leukemia cells. Am. J. Hematol., 47, 301-306. 